\title{
Women Representations in Television Narrative in the Context of Popular Culture and Turkey
}

\author{
Ph.D. Nermin Orta
}

nerminorta@gmail.com

\section{Doi:10.5901/ajis.2013.v2n8p564}

\begin{abstract}
Utterances in the products of popular culture, the culture of daily life and an escape from the negative aspects of reality, are shaped and produced by hegemonic culture of the ruling powers, thus preventing reality from being noticed. Patriarchal system, generated by or thriving on sovereign ideology and handed down from one generation to another, is a part of this ideology. One means of formation and conveyance of patriarchal system is television narrative, which is the product of popular culture. The real power of television, which is capable of reaching many people and regarded as a fundamental source of information and entertainment, lies in the fact that it has the power to shape and reshape people's points of view and that it can be the fundamental source of their thoughts and notions. With an indispensible role in spreading new radical thoughts and values, television encodes the discourses of social life into its narratives and holds its place in the integrity of the system of cultural representation which builds up the social reality by internalizing those representations. Narrations that legitimize the existing system through concrete representative strategies and the effects they have created play an important role in consolidating and normalizing the social roles of men and women by the gender representations they already possess. The aim of this study is to determine the outlook of popular television series on women, which have flourished since the year 2000 in Turkey. For this purpose, in this study, women representations in Turkish television series which rank high in ratings in Turkey and have broken viewing records in several other countries, especially in the Middle East will be investigated and it will be analyzed whether women are presented as a part of the existing ideological discourse.
\end{abstract}

\section{Introduction}

Patriarchal system, which advocates that sex is the biological reality of nature and that the social consequences should be regarded as normal due to this binding reality, is being regenerated through various theories and discourses. The main argument of sex regime which is based on sexual differences claims that sexes are the different and even contrasting biological formations of bodies. According to this common discourse, the body has always created sexual differences through genes and hormones, which legitimize the discourse of biological requirements (Sancar, 2009, 244).

Talcott Parsons, who formulated the classical American sex role model in the early 1950s, was the key figure in the structural-functional model with his theory on sex role differentiations. For Parsons, in any social system that involves both sexes, expressive interests tend to be dominant in women, while in men, instrumental interests predominate (Carrigan\&Connell\&Lee, 2002, 101-102). Power, wisdom, activeness, resistance, violence, rivalry, and passion for success and risks are indications of masculinity while the opposite characteristics are regarded to be of feminine nature (Sancar, 2009, 28-29).

Just as the man is the one who gives orders at home and just as power in the site belonged to men but not to women, slaves, or children, so should everyone make their masculine characteristics supreme over their own selves. One's being masculine against himself means ordering to those who are supposed to be ordered, forcing those who cannot govern themselves to obey, and being active against the passive or those who are supposed to be so (Foucault, 2007, 182).

According to Freud, the reason why the term "masculine" is generally regarded as active while the word "feminine" is associated with the passive is that the male sex cell is active and dynamic and chases the female cell, whereas the female egg cell remains dormant and passive (Freud, 2004, 148). The masculine role during sexual intercourse refers to an active function but the opposite is associated with the passive role of the object-partner (Freud, 2004, 153).

\section{Femininity in The Context of Gender}

The gender concept holds the opinion that a new born child has a biological sex but not a gender yet. The concept in this 
respect makes the point that gender roles are social setups caused more by social and cultural contexts than by individual sexual traits. As the child grows up, the society provides them with rules and behavior patterns specific to their sex, and these concretized patterns and models are introduced to the child by such socialization tools as family, friends, schools, and mass media. With the involvement of various learning mechanisms, the child internalizes these behaviors and acquires the gender role besides biological sex (Connell, 1998, 255). In other words, masculinity and femininity, which are formations specific to certain historical time and place, have been categories that have constantly been reshaped, resisted, regenerated, and reconfirmed in ideologies, social institutions and practices. Those males or females who violate these boundaries are subjected to countless of sanctions ranging from ridicule to violence (Segal, 1992).

In addition, in his theories on gender, Connell claims that male-female interactions are based more on power relations than on biological differences and that gender is structured through relations and hierarchy (Lusher\&Robins, 2009, 387). Connell takes the position of men and women from a different viewpoint and regards the inhibitive and still prevailing figures of understanding females as a discrimination that severs women at one whack as good girls, affectionate mothers on one hand and, on the other, as intrigant mistresses, suffocating mothers, lesbians hating males, and the ostracized with psychological disorders (Connell, 2002, 92.). According to Connell, a relatively easier admittance to the position of "good girl" brings along a disadvantage. Such feminine traps as simplicity, understanding, unconditional care and loyalty whitens females and cause them to try to be more "attractive" in line with the spiritual fantasy towards the woman. In so doing, the woman comes to think that she will have an easier access to the resident institutional structures, thereby fortifying her own imprisonment by legitimizing the semantic restriction of femininity (Connell, 2002, 101).

In conclusion, when we take the theories on history of femininity into consideration, it can be observed that some theoreticians focused on biological differences while others based their arguments on a more sociological context. An overall evaluation indicates that even if the process has functioned differently, the woman has been regarded as secondary to the man and excluded from certain places and institutions already existing in society and that biological differences and physical limitations have been used as a pretext for this.

\section{Television as the product of popular culture}

Expressions in popular culture, which is the culture of everyday life used to escape from the negative aspects of reality that produces artificial sources of happiness, has a deceptive character, is produced and shaped by the hegemonic culture of the ruling power, and therefore disguises the reality (Oktay, 2002,18-19). Popular culture which is produced by culture industry is build up in order to generate or enhance dominant ideology (Alemdar \&Erdoğan, 1994,132.)

Means of mass media constitute one of the most important tools of the dominant ideology. Used to reinforce the sovereign belief, such stereotypes as nation, family, heroism, sense of duty, and manhood are produced in those tools which make the most effective but the most covered form of propaganda of all kind and have a function of creating new forms of awareness, so that the public can internalize them (Oktay, 2002, 34).

It is observed that the media, which, in theory, is supposed to be impartial or independent while carrying out its tasks and not take orders from the those in power or distort information about the world in such a way as to make it suit the dominant concept, has already become the essential component of the process of "manufacturing consent" and is directed within the power domain of the dominant social interest represented in the state (Hall, 1999, 122.).

On the other hand, the belief that regards viewers to be passive is an old point of view, and based on the result of most recent studies, the approach that viewers are active and interact with the message actively receives more appraisals. However, not every individual is mentally healthy or intelligent at the same level, so attention is drawn on the view that the texts created by the media should be prepared by taking every personality into consideration (Yanıkkaya, 2006, 50.)

As far as the prevalence and rate of use in society are concerned, of all mass media tools, television stands as the one that must pay the most attention to this mission. The real power of television, which can reach many people and is regarded as the main source of information and entertainment, lies in the fact that it can shape people's general philosophy of life and be the fundamental source of thoughts and notions (Burton, 1995,15).

Television narratives constitute one of the conveyance and shaping-process tools of television, a powerful tool in creating distorted images of the real world, namely illusions. Aiming at people from all walks of life by telling a set of interwined stories with a wide variety of characters, television series also function as the bearer and regenerator of the existing ideological system. One of the domains that television series regenerate and legitimize is the viewpoints of femininity and masculinity that emerge linearly with the gender concept. 


\section{Women Representations in Television Series}

In recent years, Turkish television series have broken many rating records in countries from the Middle East to North Africa, Turkic Republics, Balkan States, and even Vietnam. Especially in the year 2010, more than 70 Turkish television series were observed to break export records. Owing to television series, actresses receive marriage proposals, and posters and DVDs are asked for, as well as the address of the film set. In many of the Arab countries, specifically, it is observed that the destination they want to visit most is Istanbul.

The reason why Turkish television series have become so popular is accounted for by the fact that the Arab communities would like to see 'figures that balance out the traditional with the modern'. According to Arab interpreters, 'a modern life style that does not reject conventions' appeals to Arabs, and for them, many new-but-not-alien elements exist in Turkish television series and with these elements, the sense that 'they are like us' is created. This represents a life style that Arabs want but do not have (http://www.ha.com.tr/turk-dizileri-cilginligi-254543-haber, http://www.sabah.com.tr /Ekonomi/2013/03/24/100-milyon-dolarlik-dizi-ihracati)

Turcologist-writer Amine Siljak Jesenkovic reports that Turkish television series are also highly popular in Serbia, Croatia, and Bosnia Herzegovina, besides The Middle East. She further states that this series boom started with the television series named Binbir Gece (One thousand and one nights) and adds that "People in Bosnia take more interest in Bergüzar Korel and Halit Ergenç than Angelina Jolie" and that the prejudice against Turks of Turkey has been greatly eliminated by the help of television series. ( http://www.dha.com.tr/ortadogu-ve-balkan-ulkelerinde-turk-dizileri-cilginligi _273274.html)

In the light of this information, television series can be said to have a more important function in the conveyance of culture and lifestyle than simply being an entertainment tool viewed and consumed in 1-2 hours. They also have a significant function in manufacturing and legitimizing the patriarchal discourse, and therefore, the importance of woman representations in television series is now twofold. Thus, in order to evaluate woman representations in Turkish television series, the most viewed series "Muhteşem Yüzyll" (The Magnificent Century) and "Öyle Bir Geçer Zaman Ki" (As Time Goes By) were analyzed in in the context of woman representations, independently of other aspects.

The first television series was first broadcast in 2011 and directed by Durul- Yağmur Taylan. The story is centered on the life of Suleyman The Magnificent. The story starts when the shahzadah (prince) Suleyman ascends to the throne upon his father Yavuz Sultan Selim's death and falls in love with Hurrem Sultan, a concubine brought to the royal Harem recently. However, soon events focus more on Hurrem Sultan and her affairs in Harem than Sultan Suleyman The Magnificent.

The second television series included in this study is "Oyle Bir Geçer Zaman Kl" (As time goes by), which was directed by Zeynep Günay Tan and first broadcast in 2010 and ended in 2013. The story starts in an old neighborhood in Istanbul in 1967 and continues until 1980s. While the everyday experiences of the Akarsu family is covered on one hand, economic, social and political issues of the country are also conveyed on the other. The story is monitored and narrated by Osman, the youngest son of the family.

Both television series were analyzed under certain subtopics to provide unity in analysis. The subtopics are 'the ratio of the number of male to female characters', 'personalities of women characters in main roles', 'effects of women on the relationship between men and on the course of events', and 'representation of woman characters'.

\section{Muhteşem Yüzyıl}

The television series "Muhteşem Yüzyll" is a series that has been one of the most discussed series since the first time it was broadcast. The most important reason for this controversy is that the story tells the life of Suleyman The Magnificent, one of the padishahs of the most powerful period of the Ottoman Empire; and that it focuses more on the private life of the sultan. Although the story starts with the life of Suleyman The Magnificent, it then diverts towards the affairs and life of his wife Hurrem Sultan, also a highly important figure historically. The series has often been studied academically with regard to fiction-reality relation, historical texts, social memory, sacred values, privacy, etc. However, this study focused on the women and the relations in the Harem, most of which are regarded as fiction.

The scriptwriter of the series, Meral Okay (after her death in 2012, Yılmaz Şahin became the scenarist) pointed out on a TV talk show on January $6^{\text {th }}, 2011$ that the story was a fiction-drama inspired by history and a television narrative and a fantasy, but not a documentary. She also made this distinction in her words that "although the background is based on historical realities and chronology, fiction starts with the components of private life". It is clear by the scenarist's words that relations in the Harem and the characters of women were completely shaped by the demands and preferences of the 
scriptwriter and the producers.

Emotional states underlying contradictions, disputes and behaviors of the characters and feelings of everyone living in the Harem, including the padishah, are presented in detail by the film crew. In addition, the thought that concepts such as power, greed, murder, and jealousy, which are always used to attract the viewers' attention, also existed in a place like Harem makes the events even more interesting and intrigued. The main character, Hurrem Sultan has a very suitable personality as defined by various historical narrations for the cliché "vicious, greedy, intrigued woman" sought by television series.

The other woman characters that influence the events are Suleyman's first wife Mahidevran, his sisters, Hatice Sultan and Shah Sultan, his daughter Mihrimah Sultan, his mother Ayşe Hafsa Sultan, his private servants and concubines Nigar, Gülşah, Gülfem, Afife Kalfa and Firuze. Male characters, however, are the shahzadahs (his sons), his closest friends, statesmen, and famous victories soldiers.

\subsection{The ratio of the number of male to female characters}

Depending on the data in the official website of the series, there are more female figures than male characters in the series when the guests and all the women in the Harem are counted. However, as far as influential and prolonged characters are concerned, the number of the main female characters is 11 , while that of male main characters is 15 . As was stated before, all these male characters are men in charge of governing the state, shahzadahs, and high ranking soldiers. However, female characters are women living in the Harem or managing the Harem, or the padishah's relatives. Almost all of the female guests are the princesses of other countries, relatives of high ranking statesmen, minorities residing in the country, or slaves.

\subsection{Personalities of women characters in main roles}

The central character, Hurrem Sultan is an intelligent, ambitious, passionate, and brave woman. She is an important character who can do anything for power, and she takes on an effective role in state affairs.

Suleyman's sisters Hatice and Shah Sultan also take every risk to manage the Harem and eliminate Hurrem's power. Lies and intrigues of all kinds are used for this end. Mahidevran Sultan cooperated too, but after she is sent to Manisa, she can only support them from outside. Their common desire is to ascend the oldest Shahzadah Mustafa to the throne and thus discard Hurrem Sultan and the power she possesses. Hurrem Sultan's daughter, who is involved in the story at a later stage, is not different from her mother. She has the same ambition, passion, and hatred. She enters this fight at a young age and does not hesitate to take part in all tricks of any kind.

Other women characters, most of whom are either fiction or historical figures with little information about whether they really existed, are not totally different from the main characters. Almost all the women in the Harem especially and private servants do not hesitate to betray their sultans, work for the other side, or become a part of many tricks and intrigues.

\subsection{Effects of women on the relationship between men and on the course of events}

As is explained in the section of 'personalities of women characters in main roles', almost all of both real and fiction female main characters are depicted as greedy, passionate women who can be merciless and involved in all affairs of any kind just for the sake of holding power. Every way including violence and murder is viewed as acceptable in their competition and their relations with men. In order to capture the Harem, Suleyman's sisters and Hurrem Sultan have a fierce competition, and each side kidnaps the other and applies physical violence.

However, for Hurrem Sultan, the only competition field is not limited to this arena, but she also plays every trick to intervene in the state affairs. She is historically known to play an effective role in murdering Pargali Ibrahim Pasha, Suleyman's best friend and grand vizier, and shahzadah Mustafa. She uses many statesmen including Rustem Pasha and struggles furiously to enthrone one of her sons and therefore be the only holder of the throne. She takes every chance to tempt Suleyman The Magnificent with her tricks and intrigues and plays an effective role at the government stage of the state.

Not only Hurrem Sultan but also Shah Sultan and Hatice Sultan are involved in the same greed and intrigues. After Hatice Sultan's husband Pargali is murdered, her hatred to Hurrem grows up to such an extent as for the two sisters to declare a war on Hurrem. Shah Sultan also makes use of her husband Lütfi Pasha for her own interest. Each side places 
intruders in the other's palaces, and private servants of the other side are used for information. Every woman character in the film is forced to take one side and does not go beyond being a tool for this conflict.

\subsection{Representations of woman characters}

Male characters such as Suleyman The Magnificent, Pargali Ibrahim Pasha, Shahzadah Mustafa, and Shahzadah Mehmet are depicted as calm, consistent, brave, successful, good, fair, and protective and their story is concentrated on issues such as state affairs and military achievements. Even the throne fight between the shahzadahs Mustafa and Mehmet is never voiced out between them, but on the contrary, both of them often emphasize that they are brothers. However, Hafsa Sultan, Mahidevran Sultan, Shah Sultan, Hatice Sultan, and especially Hurrem Sultan are viewed as women of greed for power who tempt men with their femininity, poison them, trap them, and blackmail them only to make their wishes come true. The throne, which is not made even a matter of an innocent talk between the shahzadahs, leads to most violent intrigues between women characters. It seems as if women are depicted to be responsible for all the vicious tricks in the palace, and all evil affairs are associated with them. Hidden or exposed sexuality of Harem fantasies is used as a tool for thrill, and the viewer watches the superior achievements and conquests made by men and the harem fights made by women. Various situations of muliebrity or women's lives and other stories that fall outside the coverage of the men's story are excluded from the film, and the emotional fluctuations and collapse of the women are superficially depicted only around wars and other games. Women are squeezed into certain types, and the story is conveyed from a masculine viewpoint.

\section{Oyle Bir Gecer Zaman Ki}

Another television series that draw attention by having a high rating is "Oyle Bir Gecer Zaman Ki". The story starts in the late 1960's and continues until 1980's. While the film is mainly focused on events happening around Akarsu Family, social, political and economical affairs in Turkey are also conveyed. Ali Akarsu, who is regarded as the head of family, is a sailor and falls in love with a dutch woman named Caroline and cheats on his wife. Cemile, the wife of Ali Akarsu, learns this. Great difficulties and negative conditions caused by these situations leaves its marks on Cemile, Ali and their children which will shape the rest of their lives. Ali and Cemile's older daughter Berrin, who is studying at university, their younger daughter, Aylin, who is studying in a high school, and their son Mete, who is at the same high school with Aylin feel that trauma deeply and their life stories are shaped under this effect. The youngest member of the family, 6-year old Osman is a person involved in and affected by all this process who observes the events, and the story is narrated by him from his own perspective. In this entire trauma, man-woman relationships and relationships of women with each other also have an important place.

In general, many clichés such as overlapping disasters, misunderstandings, lovers who can never come together, and the thought that the good always wins and the bad is destroyed in the end are repeated in this series which embodies the narrative characteristics of a melodrama. Among these repeated factors is a classical discrimination that divides women as absolute good and absolute bad (Femme Fatale).

\subsection{The ratio of the number of male to female characters}

When characters in the film are considered in general, the number of men is bigger than that of women, excluding the guest actors/actresses. While there are 18 man characters, there are only 12 woman characters. However, the number of characters that die and quit from the film is considerable. 8 men and 3 women left the series due to their deaths in the story.

\subsection{Personalities of woman characters in main roles}

The character of Cemile, one of the main characters, represents a woman who gives importance to traditional family life and tries to carry out her responsibilities in the patriarchal life system as a modest, loyal, easy-going, and honest wife and a devoted mother without questioning her gender role. Cemile and her children are frequently exposed to violence by Ali; but Cemile tries to form a link between her children and husband and hold her family together by thinking that Ali is a good person at heart and all his bad manners originate from a fractious personality of a father who loves his children very much. The violence that Ali commits is naturalized with the excuses that he does it for the good of his children, that he 
has a strict temperament by nature, and that Cemile does not satisfy him properly as a wife. Therefore, violence against women is not defined as a social problem, but as an individual issue.

The other woman character that is considered as exactly the opposite of Cemile in all manners is Caroline. Caroline, who is depicted as "foreigner" to values and cultures of the society, seducing, and a homewrecker "femme fetale", is formerly just a true love to Ali, but in the following episodes her bad behaviours rise and she turns into a woman who has nothing to sacrifice for her wills, may cheat on her husband by eliminating him if it is needed. An ideal woman/bad woman contrast is formed between Cemile and Caroline, and a rivalry between women is reinforced over this contrast. While the message that women must compete in order to obtain men, enchain them to their home, and protect their family in a male-dominated system is given, the responsibility of the man in this process is ignored, and his mistakes and violence of any kind that he committed are tolerated, forgiven, and legitimized through various excuses.

Other woman characters in the series are not different. Berrin and Aylin, Cemile's daughters, have literally the same fate; both of them have to marry other men than their beloved ones. But, in spite of everything, they do not give up and meet their lovers at the end of all difficulties. However, their happiness does not last long: Aylin dies while giving birth to her daughter and Ahmet, Berrin's husband, is assasinated. In this regard, both of them are condemned to misery.

The characters Neriman and Mesude, a mother-daughter representation, introduce another sample for relationships and envy between women. Jealous of Cemile and her daughters, Neriman and Mesude exclude and leave them out on streets even on their worst days though they are relatives. They feel happy everytime Cemile and her daughtes are in bad condition, and they even make plans for that. Thus, Neriman and Mesude come into existence as a reflection of the understanding that reduces women relationships into envy, hostility, and hatred.

\subsection{Effects of women on the relationship between men and on the course of events}

As defined in the personalities of woman characters, the relationship of woman characters that are created in the concept of good-bad conflict with men and their effect on the course of events are developing in that way. As seen in many of the stories, although men easily fall in love or leave their wives and children for their love, love for woman characters turns into an emotion that can be felt only when it is defined with loyalty as long as it does not conflict with the values of society and is secondary to her patriarchal responsibilities. Although Cemile, the absolute good of the story, tries to stand on her own feet after she is separated from Ali, she always overcomes the problems with the help of a man (fisherman, lawyer... etc. participated in the series later) and has relationships with men and get married without forgetting the expected behaviors from her, especially as a mother. On the other hand, Caroline lives all the relationships after Ali to provide personal gain. Although she has a son, she lives away from him for years, and Cemile who has to overcome all hardships becomes to one to take care of Caroline's son in spite of all that Caroline has done.

These women characters play an important role not only in relationships with each other but in relationships between men. The fisherman that comes into Cemile's life after Ali is formerly Ali's friend but after he feels something to Cemile, things become reversed and he becomes the most hated enemy of Ali due to jealousy. Men in Caroline's life show a different change. Caroline leaves Ali and has a relationship firstly with Kenan and then Ekrem. While all these men have a relation with Akarsu family and want to take revenge, this situation grows even more violent after their relationship with Caroline. The question why Caroline has a relationship with them is answered at this point. When it is assessed from this point of view, the good woman characters in the story have a positive effect on men, while bad woman characters cause a disaster or death to men.

\subsection{Representation of woman characters}

In the story which is framed around the love factor between man and woman, the woman characters are stereotyped and women are represented as absolute good and absolute bad in traditional patterns. On the one hand, there are merciful, understanding, good wife, devoted mother, and at the same time modern looking women, but on the other hand there are ambitious, lustful, merciless women who are able to use feminity as a weapon in all manners. Cemile and her daughters are considered in the first group, while Caroline, Mesude and Neriman seem closer to the second. The games and plots of these women who can use feminity as a weapon to reach their goals increase their evilness and they find the punishment at the end of the story. Therefore, the message of being punished sooner or later against a bad behaviour is given and the first group woman is blessed and woman is locked into specific stereotypes.

In the story, the only common point of these women separated as absolute good and absolute bad in the story is that both groups are exposed to violence. Cemile is raped by Ali, but even in this condition she is told that Ali cannot 
forget her and reminded of being her ex-husband and father of her children. In this way, it is implied to the audience that sexual violence is ignorable and acceptable if it is committed by an ex-husband and after a while this situation is forgotten in the narraitive. Not only Cemile, but also Aylin, Berrin, Caroline and many other woman characters are always exposed to violence by men. But all this violence is legitimized with the excuses of chastity, envy, defense, punishment, social oppression, despair, protection of family, personal problems and women are expected to be understanding and patient, show affection, be humble, ignore all the violence of men for the unity of family, obey by accepting the situation, and tame the men. Gender is rebuilt and legitimized through these created characters.

\section{Conclusion}

Partriarchal structure which is reproduced with either myths or fairy tales from our childhood, or mass communication media strengthens the position of woman in the direction of male-dominated point of view and uses any kind of device to provide the continuity of the structure. In the stories leaving the audience in the dilemma of fiction-reality through fictionalized characters in television series and events, the woman image is in an area circled by man property.

Although the booming television series in Turkey in recent years break rating records and have technically made great innovations and progress, when story concepts are considered, it is seen that they cannot develop a different argument than current patterns of patriarchal system. The television series analyzed in this study, "Muhteşem Yüzyıl" and "Öyle Bir Geçer Zaman K", which rank first in rating reports, are among the televisions series that repeat the same patterns.

"Muhteşem YuzyIl" is planned to tell the life of one of the most important sultans in Ottoman History; but after a while events focus on another historical person, Hurrem Sultan and harem life. Even though Hurrem Sultan is known by historical records as ambitious, clever, and power-hungry woman, depicting women as conspiring creatures when men are fighting in battlefield heroically or dealing with state affairs indicates that patriarchal system is adopted strongly and is repeated through the story by featuring only harem cheats, palace plots, fatal rivalry of women and power fights during fictionalizing historically real characters or creating new characters. Not only historical realities but also fictionalized lives are told through conflicts between women, and a pile of plots of intrigues, beyond a real woman story, is showed to the audience. Thus, the idea of being secondary and treacherous is reinforced through conspirator, insidious women against sensitive, clever and heroic man.

Another television series we studied, "Oyle Bir Geçer Zaman Ki", is set in the recent history of Turkey; however, the melodramatic features of the series override the features of a series of a period. The woman characters are represented as devoted mother, wife etc., as well as femme fatales. When women are emphasized in a different pattern from a "devoted mother" and "loyal, good wife", they can only exist with their male-dominated identity and this point of view presents the woman as a passive, easily-obtained, sexual-desire object to view. The woman is locked in one of two types through a continuously repeated structure totally far away from being a realistic and multi-dimensional outlook. This approach, which reinforces patriarchal system, reflects woman from male perspective and womanhood is represented with accepted values in patriarchal system. The structure that narrates these values to provide continuity of society or to objectify woman body serves only for the reproduction, normalization, and legitimization of the existing system.

\section{References}

Alemdar, Korkmaz, Erdoğan, İrfan: Popüler Kültür ve İletişim, Ümit yayıncılık, Ankara 1994.

Burton, Graeme: Görünenden Fazlası, Çev.Nefin Dinç Alan Yayıncılık, İstanbul, 1995.

Carrigan, Tim, Connell, Bob, Lee John: "Toward a New Sociology of Masculinity", Rachel Adams, David Savran, The Masculanity Studies Reader, Oxford, UK, 2002.

Connell, R.W. : Toplumsal Cinsiyet ve İktidar, Çev. Cem Soydemir, Ayrıntı Yayınları, İstanbul, 1998.

Connell,R.W.: "The History of Masculinity", Rachel Adams, David Savran, The Masculanity Studies Reader, Oxford, UK, 2002.

Foucault, Michel: Cinselliğin Tarihi, Çev: Hülya Uğur Tanrı̈̈ver, Ayrıntı Yayınları, İstanbul, 2007.

Freud, Sigmund: Psikanaliz Üzerine, Çev: A. Avni Öneş, Say Yayınları, Ankara, 2004.

Hall, Stuart: "İdeolojinin Yeniden Keşfi: Medya Çalışmalarında Baskı Altında Tutulanın Geri Dönüşü", Medya İktidar İdeoloji- Der. ve Çev. Mehmet Küçük, Ark Yayınları, Ankara, 1999.

Lusher, Dean, Robins, Garry: "Hegemonic and Other Masculinities in Local Social Context", Men and Masculinities, Volume 11 Number 4, June 2009, http://tcr.sagepub.com.

Oktay, Ahmet: Türkiye'de Popüler Kültür, Everest Yayınları, İstanbul, 2002.

Sancar, Serpil: Erkeklik:Imkansız İktidar, Metis Yayınları, İstanbul, 2009.

Segal, Lynne: "Yarışan Erkeklikler: Erkeklik-Erkek İdeali” Çev. Volkan Ersoy, Birikim, sayı: 35, Birikim Yayıncılık, İstanbul, 1998.

http://www.iha.com.tr/turk-dizileri-cilginligi-254543-haber,03.05.2013http://www.sabah.com.tr/Ekonomi/2013/03/24/100-milyon-dolarlik-dizi-ihracati 28.04.2013

http://www.dha.com.tr/ortadogu-ve-balkan-ulkelerinde-turk-dizileri-cilginligi_273274.html, 03.05.2013. 